\title{
Student's Perception of their Learning Approach and Relationship with Level of Engagement in Science Lessons
}

\author{
Nasir MAHMOOD
}

\begin{abstract}
The study focused on finding the relationship between students' proximity with constructivist principles of learning and their engagement in science lessons. Constructivist Learning Scale (CLS) by Mahmood (2004) was used to distribute students in two groups on the basis of their proximity to using constructivist learning approach for their science learning. In addition, a self-report engagement questionnaire comprising of six questions was used to record students' assessment of their own engagement at the end of each lesson while learning about "solution". The comparison of two groups showed that students exercising greater proximity to the constructivist approach toward learning had more interest, collaborated well and exceedingly involved in discussion with classfellow/teachers. Moreover, they were also more composed and meaningful in their style of writing as far as conciseness and communicability of language was concerned, as compared to students with less constructivist approach to learning.
\end{abstract}

Key words: self-engagement, constructivism, learning science

\section{INTRODUCTION}

Constructivist philosophy has remained a topic of debate on questions like generation of knowledge and its implication for teaching learning since its introduction in education. The confusion was further confounded by the introduction of a number of shades of constructivism surfaced in a very short 
time in 80's and 90's (Mahmood, 2004) by different philosophers. These differences were mostly related to philosophical questions about nature of knowledge and reality which did not have any direct bearings on teaching and learning. Therefore despite these differences on philosophical questions the potential of constructivism for promoting meaningful learning and improving achievement among students was continued to be accepted by teachers and implemented in classrooms (Boddy, Watson \& Aubsson, 2003; Driver, Asoko, Leach, Mortimor \& Scott, 1994; Mahmood, 2002; Mahmood, 2003; Osberg, 1997).

The principles of constructivist learning which enjoyed broader acceptance among teaching community involve valuing the experiences student bring to the class, appreciate the diversity, active mental and physical engagement of students in the act of learning, encourage dialogue among students and teacher and give ownership of learned to students. (Boddy, Watson \& Aubsson, 2003; Brooks \& Brooks, 1999; Gagnon, 2001).

All these principles suggest that students do not change their views about scientific concepts because someone told them to do so but instead have their own unique mechanism of learning. Therefore teaching efforts focused on helping students to get a replica of teacher's mind failed in producing meaningful learning. Consequently, a shift towards studentcentered classroom offering favorable environment, facilitating them in making knowledge for them became popular in recent pedagogies. This environment of learning requires student engagement in the concept to be learned as most crucial element of learning (Brooks M. G. \& Brooks, 1999; Perkins, 1992). This makes engagement as the most essential component of learning in the act of knowledge making.

\section{Research on student engagement in varied contexts}

There is sufficient evidence in literature to conclude that one of the challenges faced by teachers remained getting students engaged in classroom instruction (Steinberg, 1996). The evidence of this rests in the fact that a lot of research had focused on exploring factors associated to student engagement (Skinner \& Belmont, 1993; Pintrich \& DeGroot, 1990; Pintrich \& Schrauben, 1992; Nystrand \& Gamoran, 1992), examining the consistency in patterns of students engagement (Marks, 2000), and exploring the relationship of engagement and achievement (Finn, 1989, 1993; Finn and Rock, 1997). Researches have consistently reported that higher engagement in class activities indicates higher achievement and better social and cognitive involvement (Carini, Kuh \& Klein, 2006; Finn, 1993; Newmann, $1989,1991)$. Research on student engagement is carried out in two different contexts. Some researchers assume engagement is broader activity related to involvement of students in school activities and talk about school reforms 
encouraging greater student participation (Jordan \& Nettles, 1999; YazzieMintz, 2006). On the other hand there is a group of researchers who studied engagement as part of the learning activity in the classroom (Herman \& Tucker, 2000; Peterson \& Fennema, 1985). The later in fact is a part of the first but is more focused on engagement's role in learning. The common aspect in both perspectives is that students' engagement is a multidimensional (Fredricks, Blumenfield \& Paris, 2004) construct which requires students to value what they are doing, involve in deep understanding, and actively participate in class activities (Munns \& Woodward, 2006). This perspective of students' engagement is quite different than engagement associated with school activities (Natriello, 1984) and typically determined by empirically quantifying the time spent on task (Brophy, 1983; Fisher et. al., 1980; McIntyre, Copenhaver, Byrd, \& Norris, 1983) which clearly deals with students' involvement in schools.

This research is based on engagement as an indicator of involvement in specific learning task (Fredricks, Blumenfield \& Paris 2004; Skinner \& Belmont, 1993) and is assessed through level of previous knowledge, degree of interest, and involvement in class discourse during science lessons.

Engagement is a matter of degree rather than "yes" or "no" type of construct. Students do have varying degree of engagement. This research rests on the assumption that higher degree of engagement means better chances of construction of knowledge and individual differences are factor in determining the degree of engagement by individual students. Students' background plays an important role in determining the extent and nature of individual's engagement (Lee \& Smith, 1993, 1994). Students assuming learning as their responsibility, having better skills of collaboration with class fellows, more open to speak out their mind, respect others' views and assume learning as something more than better grades (constructivist approach to learning as addressed in CLS) have higher engagement in learning than others. Therefore, this research focused on finding possible difference in the ability of the grade five science students to correctly selfassess and report on measures of self-engagement in science classroom.

\section{METHODOLOGY}

Traditionally engagement studies used checklist and rating scales, selfreport measures, direct observation, work sample analysis and focused case studies (Chapman, 2003) as tools of data collection. Chapman (2003) has talked about differences between these techniques with examples of the studies in which these methods were used but did not give any clear statement of comparative advantage of any of the research methods over other methods. This research used open-ended self-report questionnaire for data collection which provided the space for recording the variety of original 
information without necessarily forcing respondents to fit their experiences in pre-structured format. This flexibility helped in highlighting the differences in the degree of self-engagement between students with different levels of constructivist approach towards their learning.

\section{PROCEDURE OF THE STUDY}

The data for this study were collected from students of grade five in January-March 2003, when they were learning about solutions. The study involved $115(38+39+38)$ students, already divided into three classes, from one of the attached elementary schools of Tokyo Gakugei University. All these classes had students of mixed ability and gender with age range of 1111.5 years.

All three classes of grade five were taught by same teacher but the sequence of lessons in three classes was not same. Therefore the content and lesson numbers were sequenced to make the comparison of reported quality of self-engagement across three classes of grade five possible as shown in table 1.

The data from phase $1,2,3 \& 5$ only was included in the analysis because at these stages all three classes have same content covered in the lesson. In case of phase 7, the students did not fill engagement questionnaire as it was last lesson and was meant to recollect what is learned in all prior lessons during this unit.

Table 1 : The scheme of lesson showing the content covered and lesson number for each class of grade five.

\begin{tabular}{|c|c|c|c|}
\hline \multirow[b]{2}{*}{ Content } & \multicolumn{3}{|c|}{ Grade 5} \\
\hline & $\begin{array}{c}\text { Section } 1 \\
(\mathrm{dd} / \mathrm{mm} / \mathrm{yy})\end{array}$ & $\begin{array}{c}\text { Section } 2 \\
(\mathrm{dd} / \mathrm{mm} / \mathrm{yy})\end{array}$ & $\begin{array}{c}\text { Section } 3 \\
(\mathrm{dd} / \mathrm{mm} / \mathrm{yy})\end{array}$ \\
\hline $\begin{array}{l}\text { Phase 1: Dissolving salt in } 50 \mathrm{ml} \text {. of } \\
\text { water and observing the changes }\end{array}$ & $\begin{array}{l}\text { Lesson } 1 \\
03 / 02 / 03\end{array}$ & $\begin{array}{l}\text { Lesson } 1 \\
28 / 01 / 03\end{array}$ & $\begin{array}{l}\text { Lesson } 1 \\
04 / 02 / 03\end{array}$ \\
\hline $\begin{array}{l}\text { Phase 2: How much salt can be } \\
\text { dissolved in } 50 \mathrm{ml} \text {. of water. }\end{array}$ & $\begin{array}{l}\text { Lesson } 2 \\
04 / 02 / 03\end{array}$ & $\begin{array}{l}\text { Lesson } 2 \\
30 / 01 / 03\end{array}$ & $\begin{array}{l}\text { Lesson } 8 \\
04 / 03 / 03\end{array}$ \\
\hline $\begin{array}{l}\text { Phase 3: Observing change in } \\
\text { volume and/or weight of solution on } \\
\text { dissolving } 10 \mathrm{gm} \text { salt in } 50 \mathrm{ml} \text { water. }\end{array}$ & $\begin{array}{l}\text { Lesson3 } \\
06 / 02 / 03\end{array}$ & $\begin{array}{l}\text { Lesson } 3 \\
13 / 02 / 03\end{array}$ & $\begin{array}{l}\text { Lesson } 5 \\
24 / 02 / 03\end{array}$ \\
\hline $\begin{array}{l}\text { Phase } 4 * \text { : Observing the effects of } \\
\text { temperature on the solubility of } \\
\text { solution. }\end{array}$ & $\begin{array}{l}\text { Lesson } 5 \\
09 / 02 / 03\end{array}$ & $\begin{array}{l}\text { Lesson } 4 \\
20 / 02 / 03\end{array}$ & $\begin{array}{l}\text { Activity not one } \\
\text { due to shortage } \\
\text { of time. }\end{array}$ \\
\hline $\begin{array}{l}\text { Phase 5: Methods of extracting salt } \\
\text { from the solution. }\end{array}$ & $\begin{array}{l}\text { Lesson } 6 \\
17 / 02 / 03\end{array}$ & $\begin{array}{l}\text { Lesson } 5 \\
25 / 02 / 03\end{array}$ & $\begin{array}{l}\text { Lesson } 7 \\
03 / 03 / 03\end{array}$ \\
\hline $\begin{array}{l}\text { Phase 6*: Making solution using } \\
\text { other solvents like boric acid. }\end{array}$ & $\begin{array}{l}\text { Lesson } 7 \\
28 / 02 / 03\end{array}$ & $\begin{array}{l}\text { Lesson } 6 \\
27 / 02 / 03\end{array}$ & $\begin{array}{l}\text { Activity not one } \\
\text { due to shortage } \\
\text { of time. }\end{array}$ \\
\hline
\end{tabular}




\begin{tabular}{|c|c|c|c|}
\hline Phase $7 *$ : Concluding the unit. & $\begin{array}{l}\text { Lesson } 8 \\
03 / 03 / 03\end{array}$ & $\begin{array}{l}\text { Lesson } 7 \\
06 / 03 / 03\end{array}$ & $\begin{array}{l}\text { Lesson } 9 \\
07 / 03 / 03\end{array}$ \\
\hline \multicolumn{4}{|c|}{ * Not included in the analysis } \\
\hline \multirow{2}{*}{\multicolumn{4}{|c|}{$\begin{array}{l}\text { 5-1: Lesson } 5 \text { was continuation of same activity as it remained incomplete in lesson } 4 \\
(07 / 02 / 2003) \text {. } \\
\text { 5-3: In lesson } 2 \& 3 \text {, students got involved in a discussion not relevant to the objectives } \\
\text { of the lesson thus lesson } 4 \text { was used to re-think the purpose of activities in last two } \\
\text { lessons and objectives to decide the future course. }\end{array}$}} \\
\hline & & & \\
\hline \multicolumn{4}{|c|}{$\begin{array}{l}\text { 5-3: Lesson } 7 \text { was continuation of lesson } 6 \text {, as students could not finish the activity in } \\
\text { time. }\end{array}$} \\
\hline
\end{tabular}

Constructivist Learner Scale (CLS) developed by Mahmood (2004) was used to classify students in two groups based on their proximity to using constructivist approach in their learning of science by using constructivist learner scale (CLS). CLS had three factors (18 items) to be responded on Likert scale (described in table 2). The higher score on CLS meant greater proximity of learning approach with constructivist demands of learning.

In addition to this classification of students they were asked to respond to questions in self-engagement sheet (described in table 3) at the end of each lesson session. The students CLS score was recorded at the beginning of the unit (solution) and on the basis of CLS score thirty students having highest score (ten from each class) and thirty students having least score (ten from each class) were selected for analyzing their self-assessment questionnaire to find the possible differences between two groups. For the purpose of simplicity the term "high CLS group" will be used for group of thirty high scoring students and "low CLS group" for thirty low scoring students on CLS.

\section{INSTRUMENTS}

Constructivist Learning Scale (CLS): This scale was developed by Mahmood (2004) and it comprised of 18 item distributed equally in three factors described in table 2.

Active involvement refers to the learner's willingness to get involved in inter-group activities and direct experiences of real life phenomenon (as much as possible) to develop his/her personal judgment. It also demands students to look at every problem from multiple perspectives and acknowledge the importance of all facets of the problem. It can also be judged by student's preference of classroom environment, which is more demanding and suitable for the active involvement like opportunities for working in small groups. Abilities like linking the previously learned concepts to the newly learned and feeling at ease while dealing with bigger concepts rather than parts of a concept also indicate the active involvement in the learning process. 
Collaboration refers to the learner characteristics demonstrating his/her comfort level in working together as team. Inter-personal behavior, readiness to accept and honor others point of view, asserting his/her thinking logically, and flexibly and using discussion as a tool of building understanding were used as indicators of learner's collaborative ability.

Items developed to determine the learner's Self-responsibility are based on the indicators like willingness to take responsibility of his/her own learning, acknowledging the role of teacher as facilitator and guide, importance of supplementary material for furthering understanding and knowledge construction, tendency of accepting challenges, and openness in discussing the problem to overcome barriers in learning.

Psychometrics of CLS: Mahmood (2004) reported Cronbach- $\alpha$ reliability of three factors of CLS; active involvement, collaboration, selfresponsibility as $0.701,0.663$ and 0.652 respectively. The overall reliability of the instrument was 0.807 . Validity of the instrument was determined through nominative method, and significant correlation $(\mathrm{p}<0.05)$ between teacher's nomination and student actual score was found. Principal component extraction was used with varimax rotation method to establish the factors reported in table 2 . The items included in the scale have factor loading 0.44 or more.

Description of the self-engagement sheet: It comprised of six questions and each question had two parts. Part one of each question was closed ended requiring students to select "yes" or "no" considering the learning activity/ experience in that particular lesson. In case of selecting 'yes', students were asked to write explanation in words. The description of the questions is given in table 3 . 
Table 2: Description of factors of Constructivist Learner Scale (CLS)

\begin{tabular}{|c|c|c|}
\hline Factor & Description & Items \\
\hline $\begin{array}{l}\text { Active } \\
\text { Involvement }\end{array}$ & $\begin{array}{l}\text { It is meant to } \\
\text { measure the extent to } \\
\text { which students are } \\
\text { willing to actively } \\
\text { engage in different } \\
\text { facets of classroom } \\
\text { learning. }\end{array}$ & $\begin{array}{l}\text { 1. Learning of science becomes easier when I have opportunity to touch, see, observe or experience } \\
\text { the actual thing by myself } \\
\text { 2. I think there can be more than one correct methods of solving a problem in science. } \\
\text { 3. I like working in small groups in my science class } \\
\text { 4. Understanding of objectives of a learning activity before performing it makes understanding } \\
\text { easier. } \\
\text { 5. I prefer learning through performing experiments/activities. } \\
\text { 6. I can find the answers of some previously not understood topics/concepts while learning new } \\
\text { topics. }\end{array}$ \\
\hline Collaboration & $\begin{array}{l}\text { This is to find out the } \\
\text { extent of students } \\
\text { characteristic of } \\
\text { working with other } \\
\text { classmates and } \\
\text { teacher during class } \\
\text { as a part of his/her } \\
\text { learning strategy }\end{array}$ & $\begin{array}{l}\text { 1. Discussion with class fellows and teachers is must for deciding the learning activities } \\
\text { 2. If the newly learned knowledge is different than already learned knowledge I discuss with my } \\
\text { teacher/friends till I understand } \\
\text { 3. Discussion with my class fellows helps me in developing understanding of science } \\
\text { 4. I accept that teacher's role is to help me when I feel difficulty in understanding rather than doing } \\
\text { every thing for me. } \\
\text { 5. I feel more confident in science class when teacher listens and understand my point of view in } \\
\text { class } \\
\text { 6. I take notes, when teacher speaks something important in the class. }\end{array}$ \\
\hline $\begin{array}{l}\text { Self- } \\
\text { responsibility }\end{array}$ & $\begin{array}{l}\text { This is to find out the } \\
\text { realization of the } \\
\text { sense of } \\
\text { responsibility among } \\
\text { the students with } \\
\text { regard to their own } \\
\text { learning. }\end{array}$ & $\begin{array}{l}\text { 1. I read books other than textbooks to have better understanding of my science lessons } \\
\text { 2. I like to take up problems, which other students say are difficult } \\
\text { 3. I think learning (studying) is my responsibility and I should do it myself } \\
\text { 4. I understand better by looking for solution to my problems by myself instead of just listening it } \\
\text { from my teacher } \\
\text { 5. I feel shy in discussing my problem related to science lessons } \\
\text { 6. I like finding material on the topics I feel interested in, during my science class }\end{array}$ \\
\hline
\end{tabular}


Table 3: Description of questions in the self- engagement questionnaire

\begin{tabular}{lll}
\hline No & \multicolumn{1}{c}{ Question } & \multicolumn{1}{c}{ Objective } \\
\hline 1. & $\begin{array}{l}\text { Did you know anything from what is learned today prior to } \\
\text { the lesson? In case you selected yes, what is that? Where you } \\
\text { learnt that? }\end{array}$ & $\begin{array}{l}\text { Find previous } \\
\text { knowledge. }\end{array}$ \\
\hline 2. & $\begin{array}{l}\text { Did you find anything interesting in today's lesson? In case } \\
\text { you selected yes, what is that? What is the reason for that? }\end{array}$ & $\begin{array}{l}\text { Determine the } \\
\text { interest in } \\
\text { lesson/learnt. }\end{array}$ \\
\hline 3. & $\begin{array}{l}\text { Do you have anything you want to know in more detail? In } \\
\text { case you selected yes, what is that? How you plan to } \\
\text { investigate/find it out? }\end{array}$ & \\
\hline 4 & $\begin{array}{l}\text { Did you participate fully in the group activities and } \\
\text { discussions? In case you selected yes, what is that } \\
\text { (activity/discussion)? }\end{array}$ & $\begin{array}{l}\text { Know the } \\
\text { usefulness of } \\
\text { group-activities } \\
\text { and collaboration } \\
\text { among students }\end{array}$ \\
& $\begin{array}{l}\text { Did you find anything helpful in group discussion or group } \\
\text { activities for today's lesson? In case you selected yes, what is } \\
\text { that? }\end{array}$ & \\
\hline 5 & $\begin{array}{l}\text { Did you have discussion or did you ask question to your } \\
\text { teacher? In case you selected yes, what was that? }\end{array}$ & $\begin{array}{l}\text { Find degree of } \\
\text { interaction with } \\
\text { teacher. }\end{array}$ \\
\hline
\end{tabular}




\section{DATA ANALYSIS}

As a first step, a question wise analysis was done to know the percentage of students who choose 'yes' from the group of students with high CLS score and low CLS score for each phase (set of lesson synchronized by content for each class) in the sequence of lessons on solution. This analysis will provide the pattern of responding by the students of both groups across the phases on each question.

In the second step, the quality of writing, conciseness and communicability of the elaboration provided in second part of each question in self- engagement questionnaire was made for each question. This analysis informed about the qualitative difference the ability of reporting in students of two groups which was not visible in mere "yes/no" response to first part of each questions in self- engagement questionnaire.

\section{RESULTS}

\section{Results for high CLS and low CLS groups}

The students of high CLS score averaged 76.5 (range of 86-71) while the average for students in low CLS score group were 38.1 (range of 37-65). The CLS comprised of 18 questions on a five-point scale thus making possible a range of 18-90 score. The results showed that the students with high CLS were more engaged in class activities than the students with low CLS score. Additional details are presented question-wise below:

Previous knowledge and its source: This question was meant to find what students think they knew about the topic studied today before coming to lesson and where did they learn it.

Figure 1 shows that although both groups started with almost same number of students reporting to know before hand (prior knowledge) about the topic to be studied i.e. apparent characteristics of solution when salt was dissolved in it. But with the progression of the unit, we can see sustainability/growth in prior knowledge about the topic to be learned in the high CLS students in comparison to students with low CLS. This improvement of involvement in the lessons as the unit progressed is clear indication of higher engagement of students from high CLS students. 


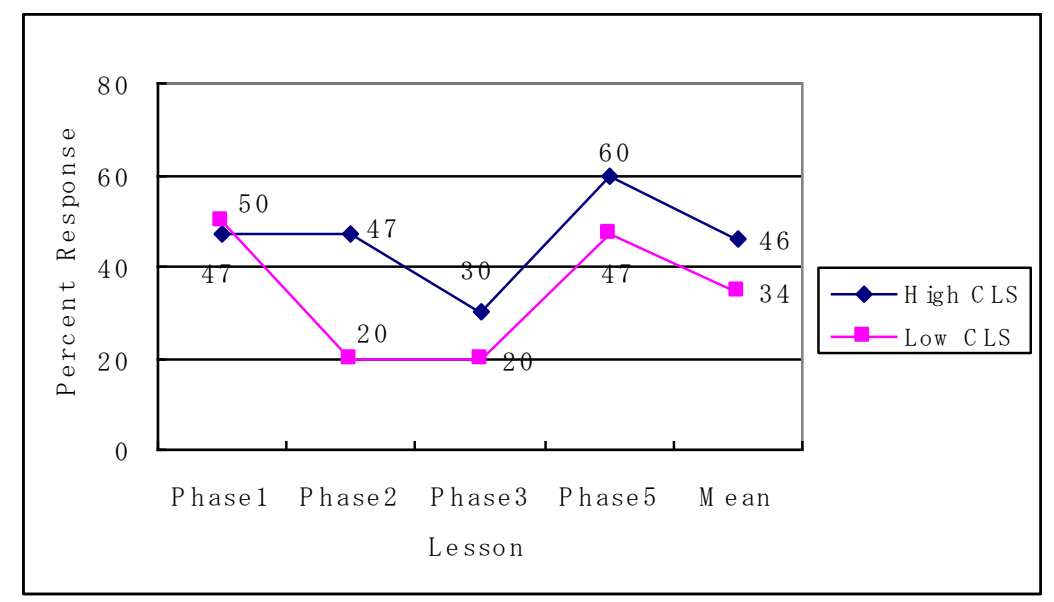

Figure 1: Question 1-comparison of previous knowledge level about the topic to be learned between high and low CLS Students

The student responding in "yes" recorded their reason for selecting "yes" in part two of the question during each phase of the unit. Table 4 shows responses of selected students (one from each high and low CLS). Difference in the conciseness, understanding of questions and communicability of used language is evident in both phase 1 and phase 5 responses.

Table 4: Difference in the quality of students' self-reporting on previous knowledge between high CLS and low CLS group

\footnotetext{
Question 1: Did you know anything about what is learned today before the lesson? In case you selected yes, what was that? Where you learnt that?

There is no change in volume even if $\quad$ Salt can be dissolved in water. (I learned it ) salt is dissolved. I read it in book.

While gargling my mouth with salt.

Student no. 8, 5-1, High CLS score Student no. 19, 5-2, Low CLS score (51), (82), Phase 1, 03/02/2003

Things are not vanished even when they Salt does not evaporate. (Heard on ) disappear. Learned in previous class.

Student no. 8, 5-1, High CLS score

(82), Phase 5, 03/03/2003 Student no. 19, 5-2, Low CLS score (51),

Phase 5, 20/02/2003

Note: Questions and student responses were originally in Japanese. Translation is done by the researcher and the Japanese class teacher then it was verified by a native speaker.

The response of high CLS students in phase 5 indicates student's interest and involvement in the lesson when he refers to the "previous lesson" while answering from where he/she learned it as compared to low
} 
CLS students referring to "television", which shows disengagement with what is going on in the class.

Development of interest in the lessons: There were two questions in the engagement questionnaire focusing on level of interest maintained in the lesson. The students with higher score on CLS have higher interest in lessons and the same pattern continued throughout the unit. Although the percentage of students' interest decreased with the progression of the unit but still more than $50 \%$ of the students at any phase of the unit found the activities in the lesson interesting. The curves almost remain parallel through out the lessons which indicate that variation in the level of interest in various phases of the unit may be due to nature of class activity itself.

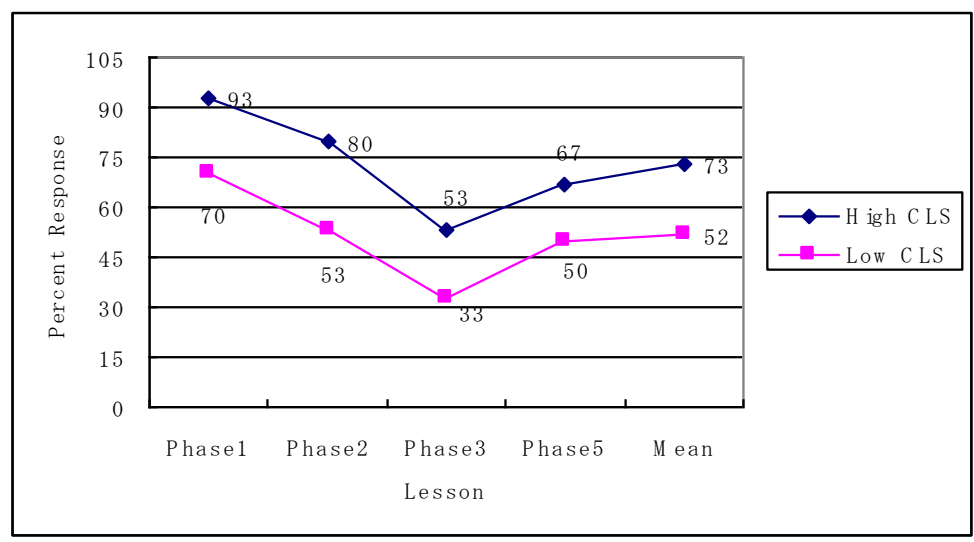

Figure 2: Question 2-difference in interest experiences of high and low CLS students

Figure 3 shows that students with high CLS have more things about which they are interested in knowing further than what they have learned in the class. There is a clear difference in the urge to know more between high and low CLS. A relatively flatter line for low CLS shows lesser motivation/involvement in the activities going on in lessons. Both groups are closest in phase 3 as the unit was coming towards its end and apparently it seems that high CLS students lost interest in the lesson but in fact it is because most of their questions were already answered and unit was heading towards closing. 


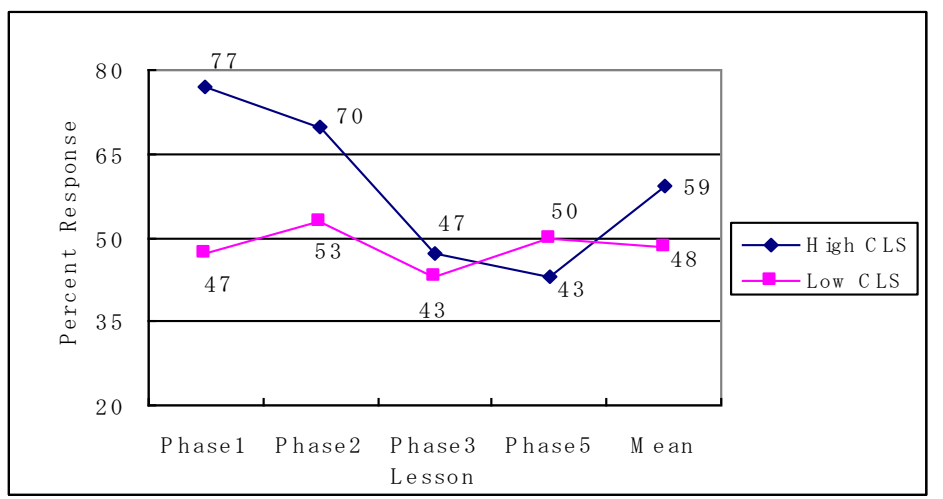

Figure 3: Question 3-Comparison of percentage of High and Low CLS on Selfengagement

The examples quoted in Table 5 are to demonstrate that students with high CLS have more scientifically oriented phenomenon in which they felt interested as compared to low CLS students showing interest in more general aspects of the lessons.

Table 5: Difference in the nature and rationale of interest between high CLS and low CLS group

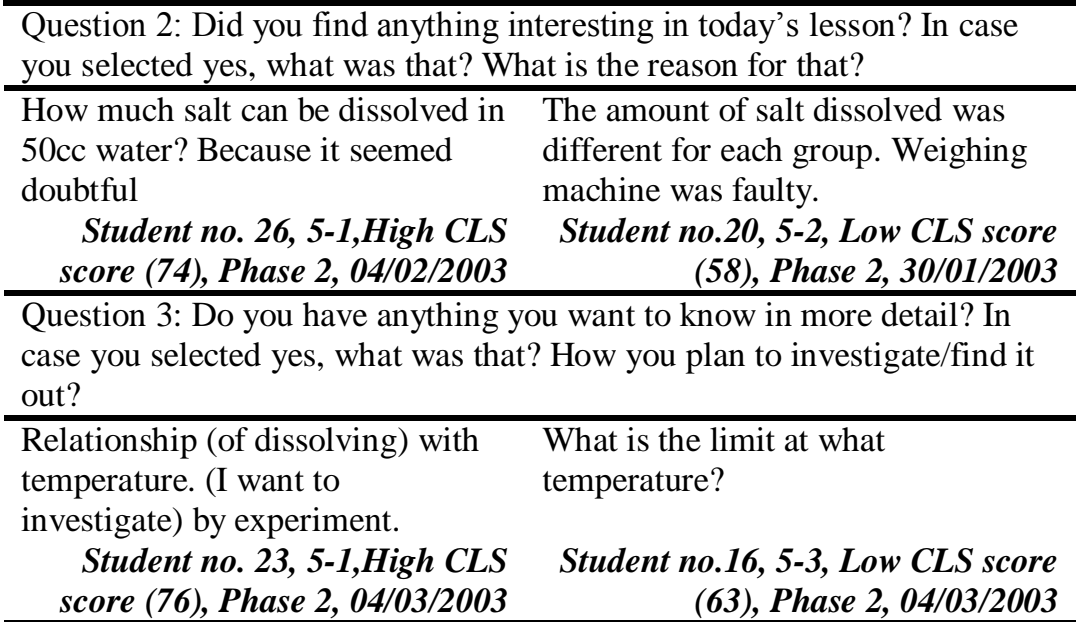

\footnotetext{
Note: Questions and student responses were originally in Japanese.

Translation is done by the researcher and the Japanese class teacher then it was verified by a native speaker.
} 
Participation in class activities and usefulness of discussion with class fellows: The result concerning the students' perceptions of the adequacy of their participation in class activities (question 4) and learning from sharing with group fellows (question 5) illustrate that the students with higher CLS score put more weight to the collaboration with other students as contributive factor in their learning as compared to students with low CLS score.

Almost half of the students with high CLS score found discussion with group fellows as valuable source in learning through out the analyzed lessons as compared to $1 / 3^{\text {rd }}$ of the students with low CLS score. One commonality found was the exceptionally high percentage reporting to have participated in class activities and collaborated in phase 2 of the lessons in Figure 4. This can be attributed to the nature of activity/content of the lessons in phase 2 (lesson 2:5-1, lesson 2: 5-2, and lesson 8: 5-3) which generated inter-group disagreement between students about the existence of quantitative limit in dissolving salt in water. Thus reaffirming the need of class activities that can instigate difference of opinion can lead toward better collaboration and in turn bringing greater class participation.

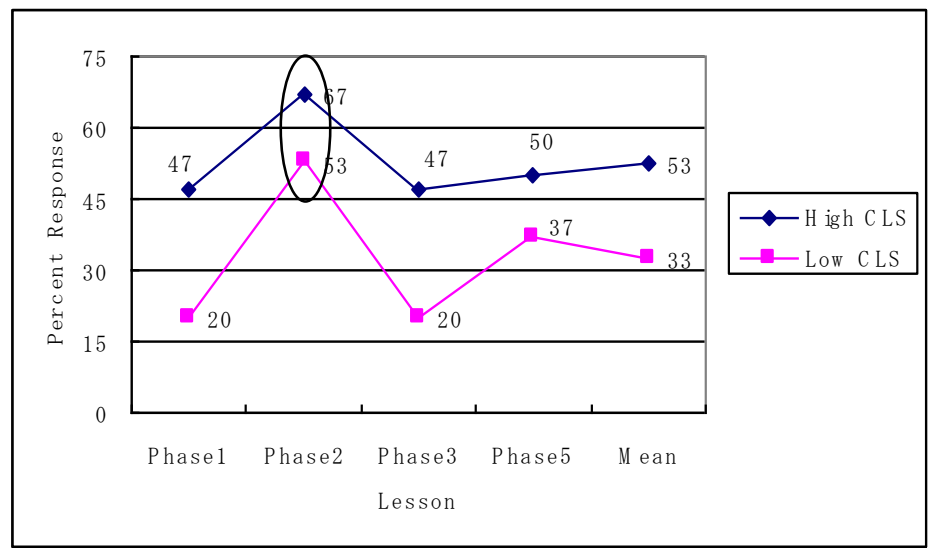

Figure 4: Question 4-comparison of percentage of high and low CLS on participation in class activities

There is an unexpected drop in the percentage of students assuming discussion with class fellows as useful for learning in phase 3, contrary to situation evident in remaining phases. We need to look into the activity going on in the class during this phase, to understand this apparently contradictory behavior. This phase involved an observatory activity in which students were involved in studying the change in weight of salt and water solution on dissolving added amount of salt at the same fixed quantity of water in every subsequent step of the observation. 


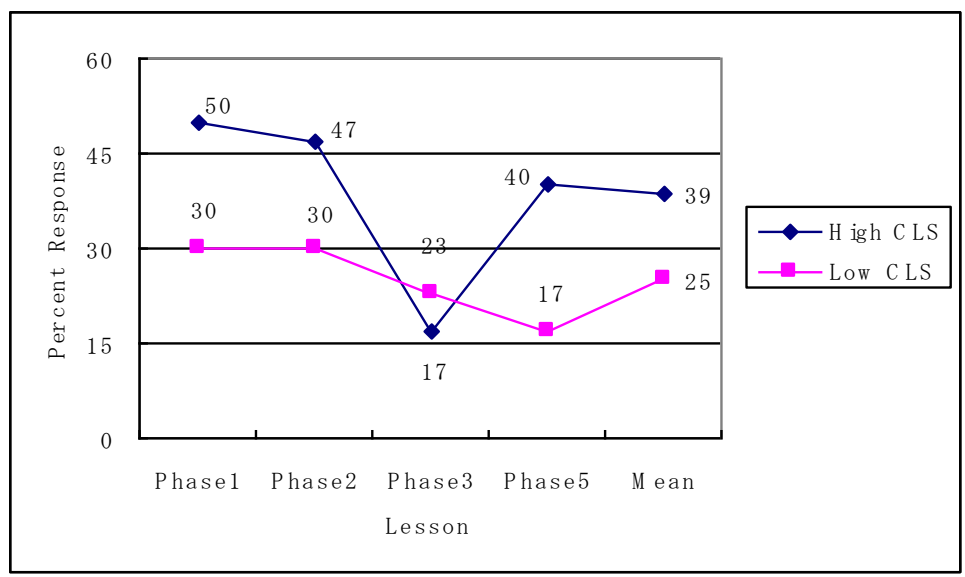

Figure 5: Question 5-comparison of percentage of high and low CLS on usefulness of discussion with class-fellows

The activity required them to dissolve a measured quantity of salt in given fix volume of water and weight it. Then add some more (already weighed) amount of salt to the same solution and weigh it again to note the change. They were to carry out this activity for five-six times and note the change in weight of solution. It was expected that the change at each step will be equivalent to the weight of the additional salt added.

Table 6: Difference in the degree of participation and discussion between high CLS and low CLS group

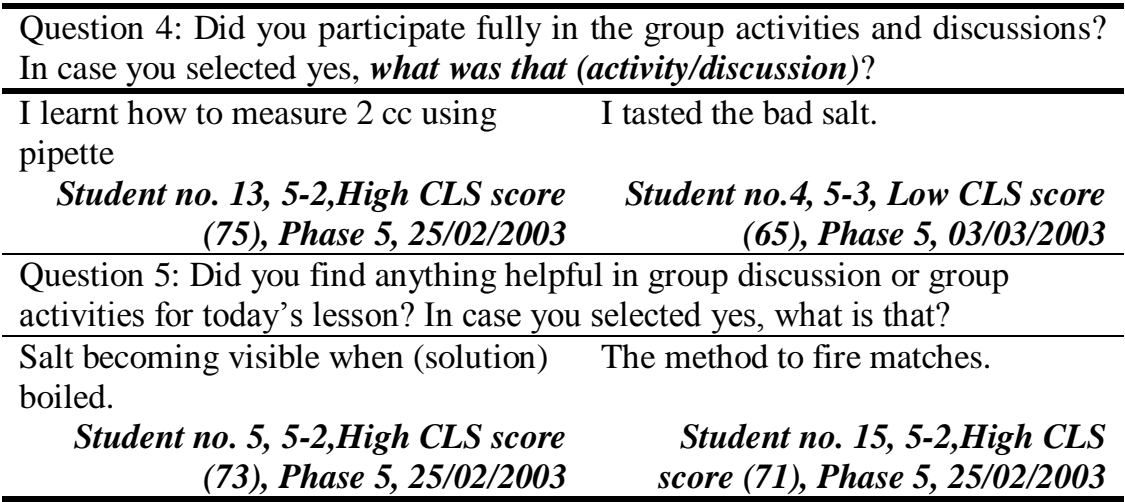

Note: Questions and student responses were originally in Japanese.

Translation is done by the researcher and the Japanese class teacher then it was verified by a native speaker. 
This phenomenon was more a common sense than science, thus having almost everyone agreeing to it. The inter-group discussion and learning from each other experiences most likely happens when there is difference of opinion among participants.

Discussion with teacher: Figure 6 shows a very low participation in discussion with teacher in both groups of students.

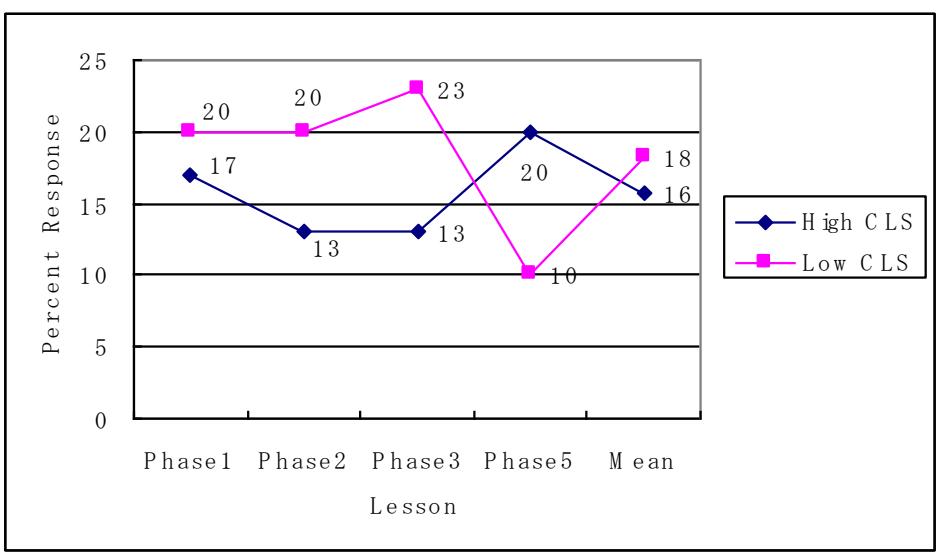

Figure 6: Question 6-Comparison of percentage of High and Low CLS on direct interaction with teacher

A review of the responses leads to the conclusion that students did not refer to the group talk between them and teacher equivalent to their one-onone talk to teacher. Therefore, their reply was affirmative only when they directly had asked some questions or had any discussion with teacher. The talk initiated by the teacher not pointing to any particular group member was not assumed by students as addressing them individually, consequently did not fall in this category. In contradiction to the rest of the questions the students of low CLS group seem to have comparatively better communication with teacher as compared to students of high CLS.

The analysis of the nature of the interaction between student and teacher revealed that interaction was limited to enquiries about the use of some experimental apparatus, writing notes or seeking instruction. It was very rare when student-teacher interaction was aimed at seeking some conceptual clarity or academic explanation of what was being learned.

Therefore it can be said that interaction basically was of two types i.e. for seeking instruction and conceptual clarity related to topic. Followings are 
the examples (in table 7) to illustrate both types of interaction when initiated by the student.

Table 7: Difference in the quality of students' prior knowledge between high CLS and low CLS group

\begin{tabular}{|c|c|c|}
\hline $\begin{array}{l}\text { Quality of } \\
\text { Response }\end{array}$ & \multicolumn{2}{|c|}{$\begin{array}{l}\text { Question 4: Did you have discussion or did you ask question to } \\
\text { your teacher? In case you selected yes, what was that? }\end{array}$} \\
\hline Conceptual & $\begin{array}{l}\text { Why salt was not left on filter } \\
\text { paper. } \\
\text { Student no. 34, 5-3,High CLS } \\
\text { score (74), Phase } 5 \text {, } \\
03 / 03 / 2003\end{array}$ & $\begin{array}{l}\text { Can we try out the experiment } \\
\text { with different conditions? } \\
\text { Student no.19, 5-1, Low CLS } \\
\text { score (54), Phase 3, 06/02/2003 }\end{array}$ \\
\hline $\begin{array}{l}\text { Seeking } \\
\text { Instruction }\end{array}$ & $\begin{array}{r}\text { About graduated cylinder } \\
\text { Student no. 11, 5-1,High CLS } \\
\text { score (76), Phase 5, } \\
09 / 02 / 2003\end{array}$ & $\begin{array}{l}\text { Where to put matches. } \\
\text { Student no.14, 5-2, Low CLS } \\
\text { score (59), Phase 5, 17/02/2003 }\end{array}$ \\
\hline
\end{tabular}

Note: Questions and student responses were originally in Japanese. Translation is done by the researcher and the Japanese class teacher then it was verified by a native speaker.

Another noticeable phenomenon across the responses given by students in low and high CLS groups was the selection of words/language for expressing their experiences in written form in the self-engagement questionnaire. A sample of the difference can be seen by scanning the responses quoted in table 5, 6 and 7. The language used by high CLS students' is relatively focused, precise in selection of words and more scientific in terms of use of terminologies acceptable in scientific literature. A consistent use of such language reflects better sense of reading science and capacity to think in scientific manner.

\section{DISCUSSION}

The results very clearly indicate that students with constructivist approach toward their learning showed greater engagement in the lesson as compared to students with less constructivist approach in quantitative terms. First interesting finding is about the difference between two groups of students in the extent to which they really got involved in the class activities to build basic knowledge for the coming lessons in the same unit. The students of high CLS group attributed most of whatever they knew in advance about topic to be studied to their learning in immediate previous lesson which indicated their mind being relatively situationally engaged in class activities as compared to the students of low CLS attributing their prior knowledge to sources outside the classroom. It also indicates that high CLS students took the lessons as sequential and knitted together which is essential for constructivist learning to happen. 
Secondly, there was a clear difference in motivation/interest level (perhaps the strongest difference) between two groups, which is a direct indicator of engagement. Interest implies the realization of relevance, meaningfulness and usability of what is being learnt by the students. This keeps students mind actively working on concepts of science by utilizing all their potential. The generation of motivation in students has remained a longstanding challenge for teachers and results of the study imply that inculcating constructivist compatible learning practices in students may indirectly be helpful in generating motivation among students towards classroom activities/lessons.

Thirdly, a recognizable difference in the quality of the scientific language used was found between the groups (refer to table 5, $6 \& 7$ ). This makes the case that students naturally having constructivist approach to learning usually write with understanding of what is being written which makes their writing more precise, academic and scientific.

Finally, the results regarding participation in class activities and collaboration with fellow students showed that students believing in constructivist principles of learning value sharing of ideas more and take it as essential condition of classroom learning. This attitude of students in class is actually helpful in changing the class environment and provides opportunity to relatively less constructivist students to engage themselves in class activities and discussions by sharing and valuing others views.

Therefore, it can be concluded that student learning practices having greater proximity to constructivist learning principles essentially instill habits of engagement in the lesson. Therefore, an intentional effort by the teacher to make classrooms requiring students to be physically and mentally involved to perform well may encourage relatively less pro-constructivist learners to change their learning practices to become more pro-constructivist learners. Thus, it can be inferred consequently that promoting constructivist learning practices will automatically result in increasing student engagement in the lessons as this is the only feasible option of learning available to constructivist learners for meaningful learning. Similarly, identification of highly pro-constructivist learners in the class and purposeful grouping of such students with low constructivist learners for a relatively longer period of time may result in bring change in learning environment of the class and ultimately producing better engaged classrooms. In this manner, by implication it can be said that encouraging schools, teachers and students to promote constructivist learning culture in classrooms can be of significant help to all of us for overcoming the problem of disengagement facing our classrooms for many years. it because engagement is the only available option to constructivist learners for meaningful learning. 


\section{REFERENCES}

Boddy, N., Watson, K. and Aubusson, P. (2003). A trial of the five Es: A referent model for constructivist teaching and learning. Research in Science Education, 33, 27-42.

Brooks, G. J. \& Brooks, G. M. (1999). In search of understanding: the case for constructivist classrooms. Alexandria: Association for Supervision and Curriculum Development.

Brooks, M. G. and Brooks, J. G. (1999). The courage to be constructivist. Educational Leadership, 57(3), 18-24.

Brophy, J. (1983). Conceptualizing student motivation. Educational Psychologist, 18, 200-215.

Carini, R. M., Kuh, G. D. \& Klein, S. P. (2006). Student engagement and student learning: Testing the linkages. Research in Higher Education, 47(1), 1-32.

Chapman, E. (2003). Alternative approaches to assessing student engagement rates. Practical Assessment, Research \& Evaluation, 8(13). $\begin{array}{llll}\text { Retrieved April } & 3, & \text { from }\end{array}$ http://PAREonline.net/getvn.asp?v=8\&n=13

Driver, R., Asoko, H., Leach J., Mortimer, E. F. \& Scott, P. (1994). Constructing scientific knowledge in the classroom. Educational Researcher, 23(7). 5-12.

Finn, J. D. (1989). Withdrawing from school. Review of Educational Research. 59, 117-142.

Finn, J. D. (1993). School engagement and students at risk. Washington D.C.: National Center for Educational Statistics.

Finn, J. D. and Rock, D. A. (1997). Academic success among students at risk. Journal of Applied Psychology. 82, 221-234.

Fisher, C., Berliner, D., Filby, N., Marliave, R., Cahen, L., \& Dishaw, M. (1980). Teaching behaviours, academic learning time, and student achievement: An overview. In C. Denham \& A. Lieberman (Eds.), Time to Learn. Washington, D.C.: National Institute of Education.

Fredricks, J. A., Blumenfield, P. C. and Paris, A. H. (2004). School engagement: Potential of the concept, state of the evidence. Review of Educational Research, 76(1), 59-109.

Gagnon Jr. W. G. and Collay M. (2001) Designing for Learning: six elements in constructivist learning, California: Corwin Press, Inc. 
Herman, K.C., \& Tucker, C.M. (2000). Engagement in learning and academic success among at-risk Latino-American students. Journal of Research and Development in Education, 33(3), 129-36.

Jordan, W. J. \& Nettles, S. M. (1999). How students invest their time out of school: Effects on school engagement, perceptions of life chances, and achievement. US Department of Education: Center for Research on the Education of Students Placed At Risk (CRESPAR).

Lee, V. E. and Smith, J. B. (1993). Effects of school restructuring on the achievement and engagement of middle-grade students. Sociology of Education, 66, 164-187.

Lee, V. E. and Smith, J. B. (1995). Effects of high school restructuring on gains in achievement and engagement of early secondary school students. Sociology of Education, 68, 241-270.

Marks, H. M. (2000). Student engagement in instructional activity: Patterns in the elementary, middle and high school years. American Educational Research Journal, 37(1), 153-184.

McIntyre, D.J., Copenhaver, R. W., Byrd, D.M. \& Norris, W. R. (1983). A study of engaged student behaviour within classroom activities during mathematics class. Journal of Educational Research, 77(1), 55-59.

Munns, G. and Woodward, H. (2006). Student engagement and student selfassessment: The REAL framework. Assessment in Education, 13(2), 193-213.

Mahmood, N. (2002) Constructivism in elementary school science education: a reflective view from inside the classroom, Journal of Educational Research, Tokyo Gakugei University, 6, pp. 1-12.

Mahmood, N. (2004). Development and validation of Constructivist learner Scale (CLS) for elementary school science students, Educational Technology Research, 27(1-2).pp.1-7.

Mahmood, N. (2003). Changes in the Students' Understanding of the Phenomenon of "Burning" in the Constructivist Classroom of Elementary School. Journal of Science education in Japan, 27(4), 270281.

Mahmood, N. (2004). Articulating philosophical and theoretical perplexities of constructivism(s) for science teachers: Ontological and epistemological perspectives, Bulletin of Education and Research, 23(12), 1-18

Natriello, G. (1984). Problems in evaluation of students and student disengagement from secondary schools. Journal of Research and Development in Education, 17, 14-24. 
Newmann, F. M. (1989). Student engagement and high school reforms. Educational Leadership, 46, 34-36.

Newmann, F. M. (1991). Student engagement in academic work: Expanding the perspective on secondary school effectiveness. In J.R. Bliss, W. A. Firetone, \& C. E. Richards (Eds.), Rethinking effective schools: Research and practice. New Jersey: Prentice-Hall.

Nystrand, M., \& Gamoran, A. (1992). Instructional discourse and student engagement. In D.H. Schunk and J.Meece (Eds.), Student Perceptions in the Classroom, New Jersey: Lawrence Erlbaum. pp. 149-179

Osberg, K. M. (1997). Constructivism in practice: the case for meaning making in the virtual world. [on line] Unpublished $\mathrm{PhD}$. thesis submitted to University of Washington. Available at: http://www.hitl. washington.edu/publications/r-97-47/osberg.rtf as on: April 21, 2005.

Perkins, N. D. (1992) What constructivism demands of a learner. In M. T. Duffy, \& H. D. Jonassen (Eds.) Constructivism and the technology of instruction, New Jersey: Lawrence Erlbaum Associates, Publishers.

Peterson, P. L. \& Fennema, E. (1985). Effective teaching, student engagement in classroom activities, and sex-related differences in learning mathematics. American Educational Research Journal, 22(3), 309-335.

Pintrich, P. R. and De Groot, E. V. (1990). Motivational and self-regulated learning components of classroom academic performance. Journal of Educational Psychology, 82(1), 33-40.

Pintrich, P. R. and Schrauben, B. (1992). Students's motivational beliefs and their cognitive engagement in classroom academic tasks. In D. S.Schunk and J.Meece (Eds.), Student perceptions in classroom. New Jersey: Lawrence Erlbaum. pp.149-179.

Skinner and Belmont (1993). Motivation in classroom: Reciprocal effect of teacher behaviour and student engagement across the second year. Journal of Educational Psychology, 82(4), 571-581.

Steinberg, L. (1996). Beyond the classroom: Why schools reform has failed and what parents need to do. New York: Simon and Schuster

Yazzie-Mintz, E. (2006). Voices of students on engagement: A report on the 2006 high school survey of student engagement, High School Survey of Student Engagement (HSSSE). Bloomington, Indiana: Center for Evaluation \& Education Policy, Indiana University, USA 